\title{
28. REDEPOSITED AND/OR REWORKED LARGER BENTHIC FORAMINIFERA FROM MIOCENE DEBRIS FLOWS, BLAKE-BAHAMA BASIN (WESTERN NORTH ATLANTIC), DEEP SEA DRILLING PROJECT LEGS 44 (SITE 391) AND 76 (SITE 534)1
}

\author{
Jacques Butterlin, Département de Géotectonique, Université Pierre et Marie Curie, 4, Place Jussieu, \\ 75230 Paris Cedex 05 France, \\ and \\ Michel Moullade, Centre de Recherches Micropaléontologiques “Jean Cuvillier," Université de Nice, Parc Valrose, \\ 06034 Nice Cedex France
}

\begin{abstract}
A detailed inventory is presented of the larger, shallow-water benthic Foraminifera incorporated in the calcareous allochthonous material that has been redeposited or reworked in the deep sediments of the Blake-Bahama Basin during the lower to middle Miocene.
\end{abstract}

\section{INTRODUCTION}

At Sites 391 and 534, located in the deep part of the Blake-Bahama Basin, drilling penetrated peculiar Miocene sediments; these rocks are mainly characterized by the occurrence of allochthonous, frequently calcareous, material, which has been introduced into a "background" pattern of sedimentation represented by siliceous mudstones thought to be deposited below the CCD (carbonate compensation depth).

Processes and possible mechanisms of this type of sedimentation (debris flows, turbidites) have been recently extensively investigated (Benson, Sheridan et al., 1978; Bliefnick et al., this volume). Among the calcareous allochthonous material, more or less abundant and medium to relatively well preserved planktonic and benthic Foraminifera have been depicted. Benthic forms appeared to be mostly represented by larger, shallow-water specimens. In Sites 391 and 534 reports, this neritic material has only been briefly mentioned. Using several hundred thin, nonoriented sections, our work attempts a more precise identification at the generic and, as often as possible, specific, level of a maximum of taxa. A comparative analysis of the resulting various stratigraphical ranges may enable us to better discriminate between the respective influences of the redeposition and reworking processes.

\section{SITE 391}

With samples from this Site we have investigated in more detail several levels containing the richest faunas of larger foraminifers, principally observed in Hole 391A, Core 12. According to Benson, Sheridan et al. (1978), this core belongs to the bottom part of their lithologic Subunit 2d, of the middle to lower Miocene.

Sample 391A-12-3, 19-23 cm This sample yielded $L e-$ pidocyclina (Eulepidina) undosa, L. (Neolepidina) $\mathrm{cf}$.

\footnotetext{
${ }^{1}$ Sheridan, R. E., Gradstein, F. M., et al., Init. Repts. DSDP, 76: Washington (U.S. Govt. Printing Office)
}

pustulosa, L. (Lepidocyclina) cf. miraflorensis, Heteroerostegina sp., Amphistegina sp. gr., lessonii and indet. Miogypsinidae. With the exception of $L$. (Neolepidina) pustulosa of the upper middle and upper Eocene, and therefore reworked, all the other macroforaminifers observed in this sample may have been contemporaneous with the in situ fauna, that is, they were probably redeposited.

Sample 391A-12-3, 66-69 cm yielded Miogypsina sp., Heterostegina sp., Sphaerogypsina sp., Amphistegina sp. gr. lessonii, all probably redeposited, and Asterocyclina sp. (middle and upper Eocene), reworked.

Sample 391A-12-5, 6-11 cm yielded Lepidocyclina (Lepidocyclina) canellei, L. (Lepidocyclina) giraudi, Miogypsina (Miogypsinita) sp., Amphistegina sp., Nummulites (s.1.) sp., probably redeposited, and Asterocycli$n a$ sp. and Fabiania cassis (middle and upper Eocene), reworked.

Sample 391A-12-5, 41-46 cm yielded Lepidocyclina (Lepidocyclina) canellei and Amphistegina sp., probably redeposited.

Sample 391A-12-5, 48-51 cm yielded $L$. (Lepidocyclina) canellei, Miogypsina (Miogypsina) sp., Amphistegina sp., Nummulites sp., probably redeposited, and $L$. (Neolepidina) macdonaldi (upper Eocene) and Vaughanina sp. (upper Senonian), reworked.

Sample 391A-12-5, 52-55 cm yielded $L$. (Lepidocyclina) giraudi, L. (Lepidocyclina) miraflorensis, Miogypsina (Heterosteginoides) sp., Nummulites sp., Heterostegina sp., Sphaerogypsina sp., Amphistegina sp., probably redeposited, and $L$. (Nephrolepidina) chaperi, L. (Neolepidina) macdonaldi, Fabiania cassis, and Asterocyclina sp., (middle and upper Eocene), reworked.

\section{SITE 534}

At this Site, Cores 534A-7, 10, 13, and 17 particularly have shown levels containing rich and allochthonous faunas of macroforaminifers (Site 534 report, this volume). By lithological correlation, these cores have been attributed to the Great Abaco Member of the Blake Ridge For- 
mation and are thought to be approximately equivalent to similar units, which had already been penetrated at Site 391 (and there referred as Subunits $2 \mathrm{~d}$ and $2 \mathrm{e}$, Benson, Sheridan, et al., 1978). As a result of a combined biostratigraphical analysis of Site $\mathbf{5 3 4}$ foraminifers and nannofossils (Site 534 report, this volume), the interval comprising Cores 534A-7 to 17 has been assigned to the lower Miocene.

Sample 534A-7-1, 54-59 cm yielded Lepidocyclina (Lepidocyclina) canellei, L. (Lepidocyclina) miraflorensis, Amphistegina sp. gr. lessonii, Miogypsina (Miogypsina) sp., Sphaerogypsina sp., probably redeposited, and Helicolepidina nortoni (middle and upper Eocene) and Vaughanina sp. (upper Senonian), reworked.

Sample 534A-7-1, 60-63 cm yielded $L$. (Lepidocyclina) canellei, L. (Lepidocyclina) cf. yurnagunensis, probably redeposited.

Sample 534-10-4, 66-71 cm yielded L. (Lepidocyclina) canellei, Lepidocyclina sp., Amphistegina sp. gr. lessonii, Miogypsina (Miogypsina) sp., Heterostegina sp., probably redeposited.

Sample 534A-13-1, 86-88 cm yielded $L$. (Lepidocyclina) canellei, Miogypsina sp., Amphistegina sp., probably redeposited.

Sample 534A-13-1, 137-141 cm yielded L. (Lepidocyclina) canellei, Heterostegina sp., probably redeposited, and L. (Neolepidina) macdonaldi (upper Eocene), reworked.

Sample 534A-13-2, 78-82 cm yielded Heterostegina cf. antillea, probably redeposited.

Sample 534A-17-7, 10-15 cm yielded $L$. (Lepidocyclina) canellei, L. (Lepidocyclina) miraflorensis, L. (Lepidocyclina) waylandvaughani, L. (Lepidocyclina) giraudi, L. (Lepidocyclina) cf. yurnagunensis, L. (Eulepidina) undosa, Miogypsina sp., Nummulites sp., probably redeposited, and indet. Discocyclinidae (Paleocene-Eocene), reworked.

Sample 534A-17-7, 16-18 cm yielded $L$. (Lepidocyclina) canellei, L. (Lepidocyclina) giraudi, Amphistegina sp. gr. lessonii, Miogypsinoides sp., Heterostegina sp., probably redeposited, and $L$. (Neolepidina) macdonaldi, L. (Neolepidina) pustulosa pustulosa, Dictyoconus floridanus, and Asterocyclina sp., (middle and upper Eocene), reworked.

Sample 534A-17-7, 28-30 cm yielded $L$. (Lepidocyclina) canellei, L. (Eulepidina) cf. undosa, Heterostegina cf. antillea, indet. Miogypsinidae, probably redeposited.

Sample 534A-17-7, 32-35 cm yielded $L$. (Lepidocyclina) canellei, L. (Lepidocyclina) giraudi, Heterostegina antillea, $H$. panamensis, Nummulites sp., Miogypsina sp., Sphaerogypsina sp., Amphistegina sp., probably redeposited, and L. (Neolepidina) macdonaldi, L. (Neolepidina) pustulosa pustulosa, Fabiania cassis, Dictyoconus floridanus, and Asterocyclina sp. (middle and upper Eocene), reworked.

Sample 534A-17,CC yielded $L$. (Lepidocyclina) canellei, L. (Lepidocyclina) giraudi, L. (Lepidocyclina) miraflorensis, L. (Lepidocyclina) cf. yurnagunensis, $L$. (Eulepidina) undosa, L. (Polylepidina) antillea, Heterostegina antillea, $H$. panamensis, Miogypsina sp., Mio- gypsinoides sp., Amphistegina parvula, A. sp. gr. lessonii, Amphistegina sp., Nummulites sp., probably redeposited, and L. (Neolepidina) pustulosa pustulosa, L. (Neolepidina) macdonaldi, L. (Nephrolepidina) chaperi, Asterocyclina minima, Asterocyclina sp., Fabiania cassis, (middle and upper Eocene), reworked.

\section{REDEPOSITION AND REWORKING: POSSIBLE ORIGIN OF THE ALLOCHTHONOUS SHALLOW- WATER BENTHIC MATERIAL}

The most significant result derived from our observations is that an important part of the shallow-water macroforaminifers are of the early Miocene, that is, they are contemporaneous with the younger age given by the presumably "in situ" (or possibly also transported, see Benson, Sheridan, et al., 1978) accompanying pelagic microfauna.

This result may suggest that part of the neritic organisms have been transported from the inner continental shelf, for instance, by turbidite and/or combined turbidite-debris flow processes, and redeposited in the deep sediments of the Blake-Bahama Basin.

However, erosion and faunal reworking are also indicated by the simultaneous occurrence, in the studied material, of macroforaminifers of an older age, most often middle to upper Eocene, more rarely upper Senonian. There is no peculiar evidence that the amount of reworked specimens increases downward or upward. This parameter does appear to be better linked with the variations of intensity of the erosional processes.

Benson, Sheridan, et al., (1978) suggested the Bahama channels, where shallow marine Tertiary sediments crop out, as a possible source of the allochthonous shallow-water benthic forms. We may also note that assemblages of redeposited and reworded macroforaminifers, which have been observed in the lower Miocene sediments penetrated at Sites 391 and 534, are very similar to those described from neighboring areas, like Florida, Georgia, the Gulf Coast, and the Greater Antilles (particularly Cuba and Haiti) (Cole 1938, 1941-1945, 1964, 1967; Cole and Applin, 1961, 1964; Drooger, 1952; Akers and Drooger, 1957; Butterlin, 1981).

\section{ACKNOWLEDGMENTS}

The authors wish to express their gratitude to their colleagues Dr. Gérard Bignot, Dr. Alphonse Blondeau, and Dr. Claude Lorenz (University of Paris VI, France), who kindly reviewed this manuscript. Dr. Moullade thanks DSDP for inviting him to participate in Leg 76 and providing additional samples, and the Centre National pour l'Exploitation des Océans (CNEXO), which provided assistance for travel expenses. Financial support for this investigation was furnished by the Centre National de la Recherche Scientifique (CNRS) under Grant "A.T.P. Géologie-Géophysique des Océans" No. 096.

\section{REFERENCES}

Akers, W. H., and Drooger, C. W., 1957. Miogypsinids, planktonic foraminifera, and Gulf-Coast Oligocene-Miocene correlations. Am. Assoc. Pet. Geol. Bull., 41:656-678.

Benson, W. E., Sheridan, R. E., and Shipboard Scientific Party, 1978. Site 391: Blake-Bahama Basin. In Benson, W. E., Sheridan, R. E., et al., Init. Repts. DSDP, 44: Washington (U.S. Govt. Printing Office), 153-336.

Butterlin, J., 1981. Claves para la Determinacion de Macroforaminiferos de Mexico y del Caribe, del Cretacico Superior al Mioceno 
Medio. Mexico City, Mexico (Instituto Mexicano del Petroles), pp. 1-219.

Cole, W. S., 1938. Stratigraphy and micropaleontology of two deep wells in Florida. Fla. Geol. Surv. Bull., 16:1-73.

1941-1945. Stratigraphic and paleontologic studies of wells in Florida. Fla. Geol. Surv. Bull., 19(1, 1941):1-91; 20(2, 1942): $1-89 ; 26(3,1944): 1-29 ; 28(4,1945): 1-160$.

1964. American Mid-Tertiary Miogypsinid Foraminifera: classification and zonation. Contrib. Cushman Found. Foraminiferal Res., 15:138-150.

1967. A review of American species of Miogypsinids (larger Foraminifera). Contrib. Cushman Found. Foraminiferal Res., 18: 99-117.
Cole, W. S., and Applin, E., 1961. Stratigraphic and geographic distribution of certain larger Foraminifera occurring in a well of Coffee County, Georgia. Contrib. Cushman Found. Foraminiferal Res., 12:127-135.

1964. Problems of the geographic and stratigraphic distribution of American Middle Eocene larger Foraminifers. Bull. Am. Paleontol., 47:1-48.

Drooger, C. W., 1952. Study of American Miogypsinidae [Thesis]. Utrecht University.

Date of Initial Receipt: October 27, 1982 

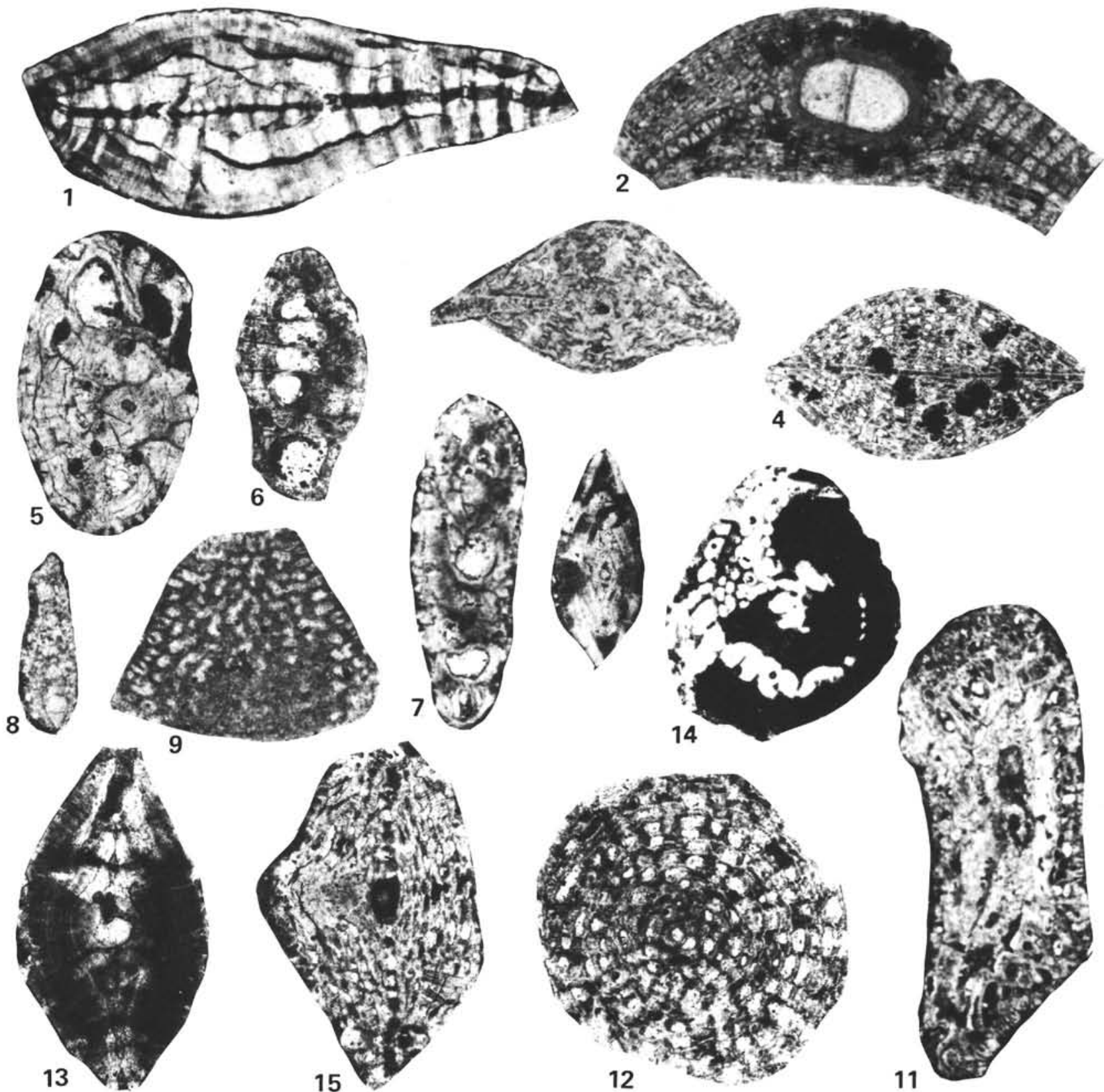

Plate 1. Larger benthic Foraminifera from Miocene debris flows. (All specimens with the exception of Figs. 1, 2, 8-11, and 14 are magnified $\times 40$.) 1. Heterostegina cf. antillea Cushman, $\times 17$, subaxial section. Sample $534 \mathrm{~A}-13-2,78-82 \mathrm{~cm}$. 2. Lepidocyclina (Lepidocyclina) miraflorensis Vaughan, $\times 26$, axial section. Sample 391A-12-5, 52-55 cm. 3. Vaughanina sp. subaxial section. Sample 391A-12-5, 48-51 cm. 4. Asterocyclina sp. subaxial section. Sample $391 \mathrm{~A}-12-5,52-55 \mathrm{~cm}$. 5-7. Miogypsinoides sp. (5) subequatorial section. Sample 534A-17,CC. (6) Axial section. Sample 534A-17-7, 16-18 cm. (7) Axial section. Sample 534A-17,CC. 8. Miogypsina (Miogypsina) sp., $\times 17$, axial section. Sample 534A$17-7,32-35 \mathrm{~cm}$. 9. Dictyoconus floridanus (Cole), $\times 26$, subaxial section. Sample 534A-17-7, 32-35 cm. 10. Amphistegina sp., $\times 17$, axial section. Sample 534A-17-7, 32-35 cm. 11. Fabiania cassis (Oppenheim), $\times 26$, transverse section. Sample 534A-17,CC. 12. Sphaerogypsina sp., radial section. Sample 534A-7-1, 54-59 cm. 13. Heterostegina panamensis Gravell, axial section. Sample 534A-17-7, 32-35 cm. 14. Heterostegina cf. antillea Cushman, $\times 17$, subequatorial section. Sample 534A-17,CC. 15. Helicolepidina nortoni Vaughan, subaxial section. Sample 534A-7-1, 54-59 cm. 


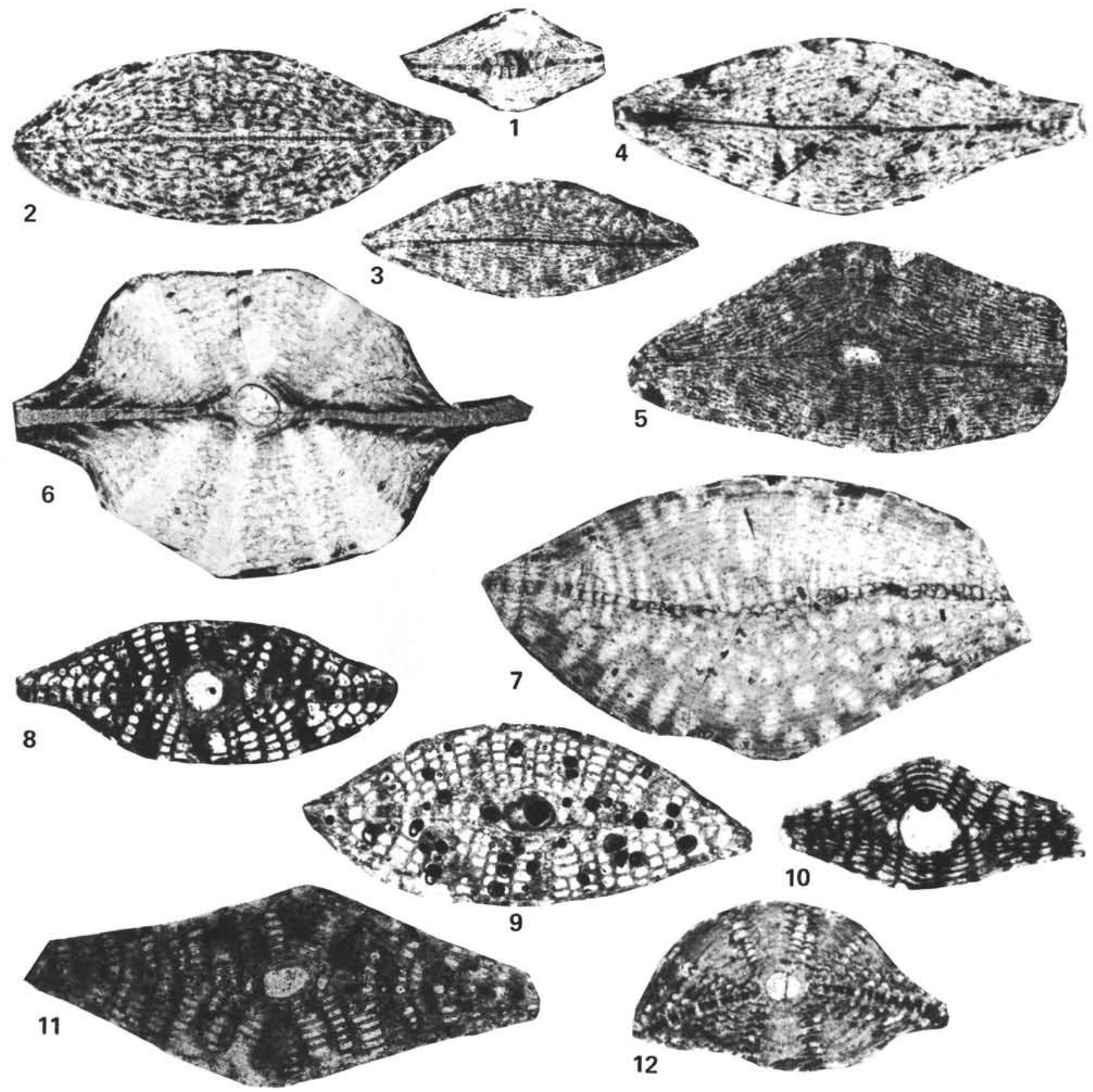

Plate 2. Larger benthic Foraminifera from Miocene debris flows. (All specimens with the exception of Figs. 3, 6-7, 10, and 12 are magnified $\times 40$.) 1-4, 25. Asterocyclina sp., subaxial sections. (1-3) Sample 534A-17-7, 32-35 cm (Fig. 3, $\times 26$ ). (4) Sample 534A-17-7, 16-18 cm. (5) Sample 534A-17,CC. 6-7. Lepidocyclina (Eulepidina) undosa Cushman, $\times 17$, subaxial sections. Sample 534A-17,CC. 8-9. Lepidocyclina (Lepidocyclina) canellei Lemoine and Douvillé, axial sections (8) Sample 534A-17-7, 10-15 cm. (9) Sample 534A-17,CC. 10-11. Lepidocyclina (Lepidocyclina) cf. yurnagunensis Cushman, axial sections. Sample 534A-17,CC. (Fig. 10, $\times 26$ ). 12. Lepidocyclina (Lepidocyclina) giraudi Douvillé, subaxial section, $\times 26$. Sample 534A-17-7, 32-35 cm. 

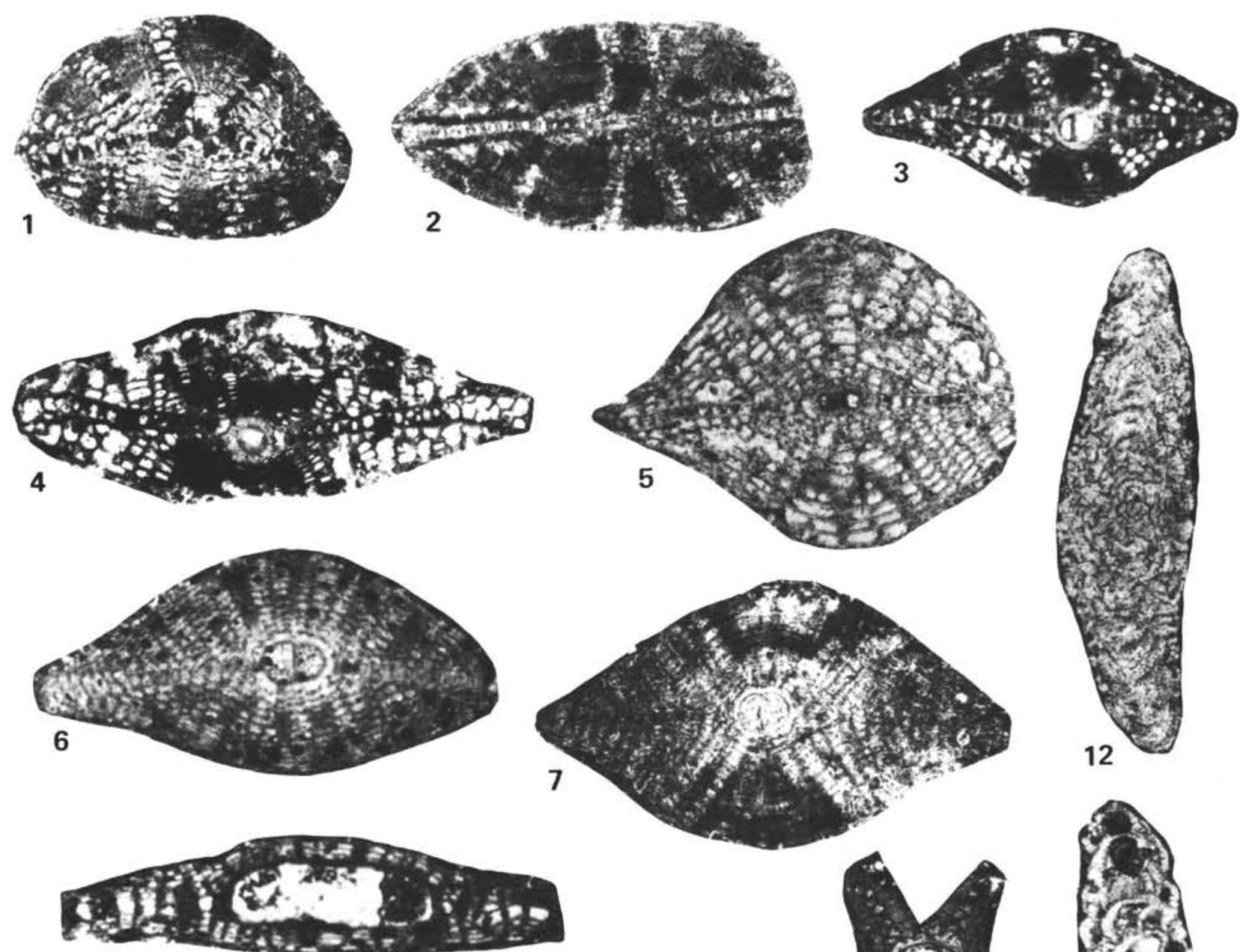

8
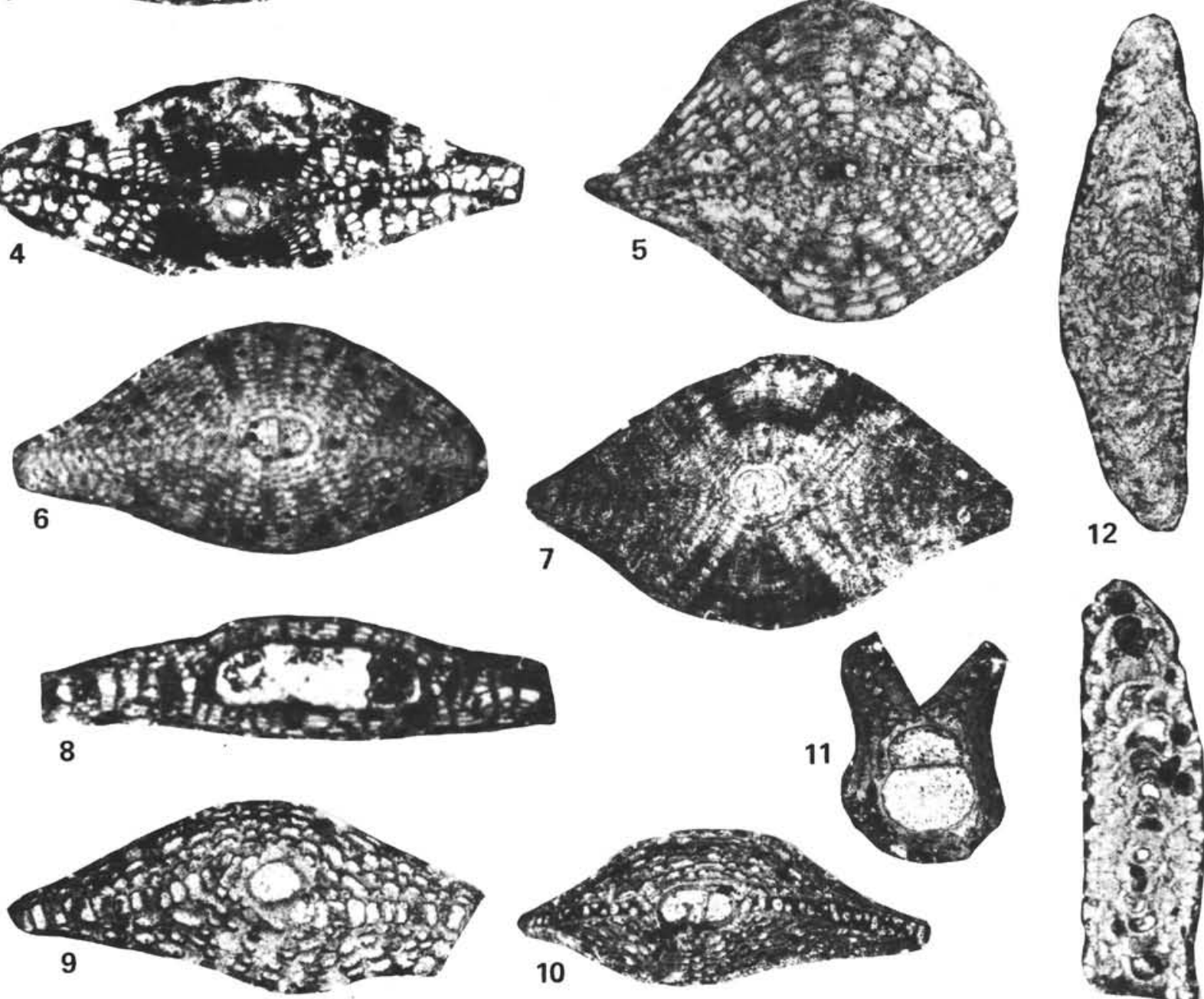

12

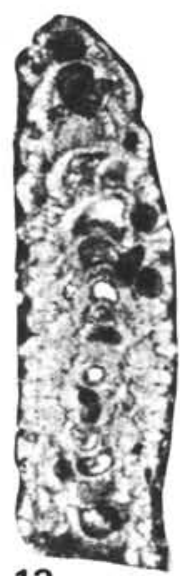

13

Plate 3. Larger benthic Foraminifera from Miocene debris flows. (All specimens with the exception of Figs. 8 and $11-13$ are magnified $\times 26$. .). 1-3. Lepidocyclina (Lepidocyclina) giraudi Douvillé (1-2) subaxial sections. Sample 534A-17-7, 32-35 cm. (3) Axial section. Sample 534A-17-7, 16-18 cm. 4. Lepidocyclina (Lepidocyclina) miraflorensis Vaughan, subaxial section. Sample 534A-7-1, 54-59 cm. 5-7. Lepidocyclina (Neolepidina) pustulosa pustulosa Douvillé (5) axial section. Sample 534A-17-7, 16-18 cm. (6) Axial section. Sample 534A-17,CC. (7) Axial section. Sample 534A-17-7, 32-35 cm. 8. Lepidocyclina (Nephrolepidina) chaperi Lemoine and Douvillé, $\times 17$, axial section. Sample 534A-17,CC. 9-11. Lepidocyclina (Neolepidina) macdonaldi Cusman (9-10) axial sections. Sample 534A-17-7, 32-35 cm. (11) Embryonic zone, $\times 17$. Sample 534A-17-7, 16-18 cm. 12-13. Gypsina vesicularis (Parker and Jones), $\times 40$, axial sections. (12) Sample 534A-17-7, 32-35 cm. (13) Sample 534A-17,CC. 